\title{
Catalog of Mount St. Helens 2004-2007 Dome Samples with Major- and Trace-element Chemistry
}

By Carl R. Thornber, John S. Pallister, Michael C. Rowe, Siobhan McConnell, Trystan M. Herriott, Alison Eckberg, Winston C. Stokes, Diane Johnson Cornelius, Richard M. Conrey, Tammy Hannah, Joseph E. Taggart Jr., Monique Adams, Paul J. Lamothe, James R. Budahn and Charles M. Knaack

This report presents a catalog of sample information and bulk-rock geochemical data for newly erupted rocks collected near the vent in Mount St. Helens crater between October 2004 and October 2007. An overview of sample collection and lithology along with specifics of analytical techniques are presented as a PDF file, which also includes a detailed explanation of sample information categories that are tabulated in spreadsheets. The Mount St. Helens 2004-2007 Dome Sample Catalog and geochemical data are downloadable in a separate Microsoft Excel file.

Open-File Report 2008-1130

\section{U.S. Department of the Interior \\ U.S. Geological Survey}




\section{U.S. Department of the Interior DIRK KEMPTHORNE, Secretary}

\section{U.S. Geological Survey Mark D. Myers, Director}

U.S. Geological Survey, Reston, Virginia 2008

For product and ordering information:

World Wide Web: http://www.usgs.gov/pubprod

Telephone: 1-888-ASK-USGS

For more information on the USGS - the Federal source for science about the Earth, its natural and living resources, natural hazards, and the environment:

World Wide Web: http://www.usgs.gov

Telephone: 1-888-ASK-USGS

Suggested citation:.

Thornber, C.R., Pallister, J.S., Rowe, M.C., McConnell, S., Herriott, T.M., Eckberg, A., Stokes, W.C., Johnson Cornelius, D., Conrey, R.M., Hannah, T., Taggert, J.E., Adams, M., Lamothe P.J., Budahn J.R., and Knaack, C.M., 2008, Catalog of Mount St. Helens 2004-2007 Dome Samples with Major- and Trace-element Chemistry: U.S. Geological.Survey Open File Report 2008-1130

Any use of trade, product, or firm names is for descriptive purposes only and does not imply endorsement by the U.S. Government.

Although this report is in the public domain, permission must be secured from the individual copyright owners to reproduce any copyrighted material contained within this report. 


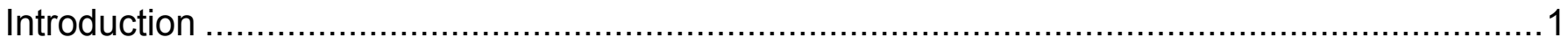

Overview of Mount St. Helens 2004-2007 Dome Sample Suite ............................................

Explanation of the Mount St. Helens 2004-2007 Dome Sample Catalog …...............................

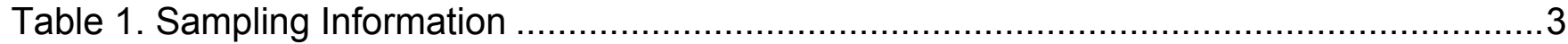

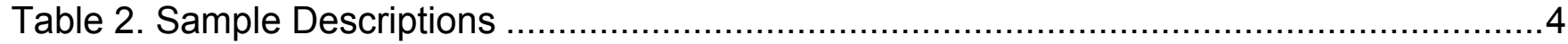

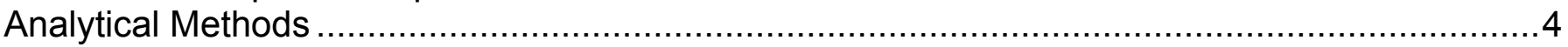

Chemistry of Mount St. Helens 2004-2007 Dome Samples …........................................

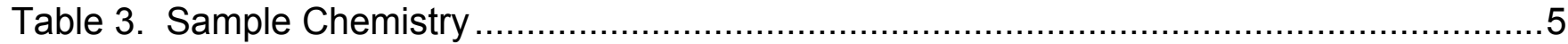

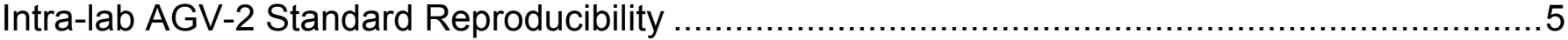

Table 4. Major-Element Analyses of U.S.Geological Survey Geochemical Reference Standard

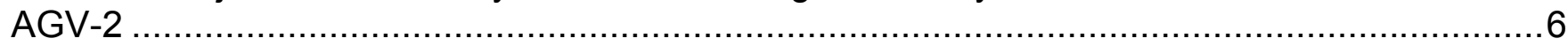

Table 5. Trace -Element Analyses of U.S.Geological Survey Geochemical Reference Standard

AGV-2

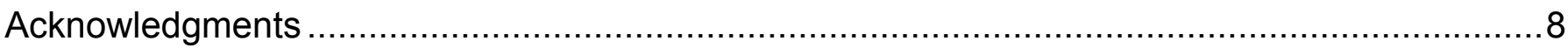

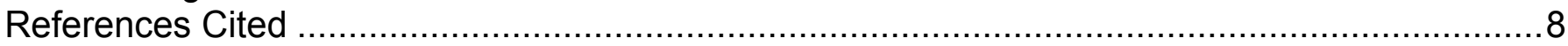




\title{
Catalog of Mount St. Helens 2004-2007 Dome Samples with Major- and Trace-element Chemistry
}

\author{
By Carl R. Thornber ${ }^{1}$, John S. Pallister ${ }^{1}$, Michael C. Rowe ${ }^{2}$, Siobhan McConnell ${ }^{3}$, \\ Trystan M. Herriott ${ }^{4}$, Alison Eckberg ${ }^{5}$, Winston C. Stokes ${ }^{1}$, Diane Johnson Cornelius ${ }^{6}$, \\ Richard M. Conrey ${ }^{6}$, Tammy Hannah ${ }^{7}$, Joseph E. Taggart Jr. ${ }^{7}$, Monique Adams ${ }^{7}$, Paul J. \\ Lamothe $^{7}$, James R. Budahn ${ }^{7}$ and Charles M. Knaack ${ }^{6}$
}

\section{Introduction}

Sampling and analysis of eruptive products at Mount St. Helens is an integral part of volcano monitoring efforts conducted by the U.S. Geological Survey's Cascades Volcano Observatory (CVO). The objective of our eruption sampling program is to enable petrological assessments of pre-eruptive magmatic conditions, critical for ascertaining mechanisms for eruption triggering and forecasting potential changes in eruption behavior. This report provides a catalog of near-vent lithic debris and new dome-lava collected during 34 intra-crater sampling forays throughout the October 2004 to October 2007 (2004-7) eruptive interval at Mount St. Helens. In addition, we present comprehensive bulk-rock geochemistry for a time-series of representative (2004-7) eruption products. This data, along with that in a companion report on Mount St. Helens 2004 to 2006 tephra by Rowe and others (2008), are presented in support of the contents of the U.S. Geological Survey Professional Paper 1750 (Sherrod and others, eds., 2008). Readers are referred to appropriate chapters in USGS Professional Paper 1750 for detailed narratives of eruptive activity during this time period and for interpretations of sample characteristics and geochemical data. The suite of rock samples related to the 2004-7 eruption of Mount St. Helens and presented in this catalog are archived at the David A. Johnson Cascades Volcano Observatory, Vancouver, WA.

The Mount St. Helens 2004-7 Dome Sample Catalogue with major- and trace-element geochemistry is tabulated in 3 worksheets of the accompanying Microsoft Excel file, OF20081130.xls. Table 1 provides location and sampling information. Table 2 presents sample

\footnotetext{
${ }^{1}$ U.S. Geological Survey, 1300 SE Cardinal Court,Vancouver, WA 98683

${ }^{2}$ Department of Geosciences, 104 Wilkinson Hall, Oregon State University, Corvallis, OR 97331; now at Department of Geoscience, 121 Trowbridge Hall, University of Iowa, Iowa City, IA 52242

${ }^{3}$ Portland Community College, P.O. Box 19000, Portland, OR 97280-0990

${ }^{4}$ Department of Earth Science, Webb Hall, University of California, Santa Barbara, CA 93106; now at P.O. Box 750255, Fairbanks, AK 99775

${ }^{5}$ USDA Forest Service, Mount St. Helens National Volcanic Monument, 42218 NE Yale Bridge Rd, Amboy, WA 98601; now at U.S. Geological Survey, Denver Federal Center, Box 25046, Denver, CO 80225

${ }^{6}$ GeoAnalytical Laboratory, School of Earth and Environmental Sciences, Webster 1228, Washington State University, Pullman, WA 99164-2812

${ }^{7}$ U.S. Geological Survey, Denver Federal Center, Box 25046, Denver, CO 80225
} 
descriptions. In table 3, bulk-rock major and trace-element geochemistry is listed for 44 eruptionrelated samples with intra-laboratory replicate analyses of 19 dacite lava samples.

A brief overview of the collection methods and lithology of dome samples is given below as an aid to deciphering the dome sample catalog. This is followed by an explanation of the categories of sample information (column headers) in Tables 1 and 2. A summary of the analytical methods used to obtain the geochemical data in this report introduces the presentation of majorand trace-element geochemistry of 2004-7 Mount St. Helens dome samples in table 3. Intralaboratory results for the USGS AGV-2 standard are presented (tables 4 and 5), which demonstrate the compatibility of chemical data from different sources.

\section{Overview of Mount St. Helens 2004-2007 Dome Sample Suite}

From October 2004 to October 2007, seven successive lava spines arose from the vent. Each spine emerged with sheared and fault-gouged outer margins, developed during forceful expulsion of a near-solid dacite lava plug. This rubbley dome-building eruption was punctuated by massive rock falls from over-steepened spines of lava that were crushed together during nearcontinuous extrusion. Throughout this eruptive interval, hazardous eruption conditions prohibited near-vent sampling forays on the ground. Sampling of newly erupted material was therefore mostly limited to "helidredging" of talus blocks and lithic debris shed during the continuous growth and collapse of the lava dome. The dredging device, dubbed "Jaws" by it's creators at CVO, is a longhandled, steel-plated, open-faced box $(60 \mathrm{~cm} \times 30 \mathrm{~cm} \times 30 \mathrm{~cm})$ with serrated tooth-like edges gaping at the top and a chain-mail basket (or steel box) at the bottom. Jaws was slung beneath a helicopter on a $30 \mathrm{~m}$ cable. Helidredging hot fresh rock from the face of the emergent dome was a challenging task under the most favorable conditions and required a highly skilled pilot teamed with an unflappable geologist, and an alert observational support team stationed on the crater rim.

October 2004 ash and rock samples (SH300-SH302) derived from debris and talus around a nascent dome presented a complex mixture of materials. With 20/20 hindsight and in the light of the first sampling of unequivocally new dome material in late October and early November 2004, it became apparent that a significant proportion of early ash was comprised of preexisting crater rock and debris.

Subsequent samples derived from each of seven successive lava spines range in lithologic facies from igneous to cataclastic. The bulk of the new dome lava is a porphyritic dacite with plagioclase, amphibole, orthopyroxene, and iron-titanium-oxide phenocrysts in a microcrystalline groundmass. The dacite lava ranges in color from light gray to pink or reddish. The red coloration results from late-stage oxidation reactions involving amphibole and oxide phenocrysts. In many samples, this alteration is pervasively distributed along matrix grain boundaries and localized in microscopic cracks along foliation planes. This is a likely source of secondary red encrustation along jointed surfaces of otherwise pristine dacite talus blocks. Vesicularity of 2004-7 dacite lava ranges from less than 10 volume percent in typical dense light gray lava to about 40 volume percent in flow-banded, pinkish colored, vesicular lava that was collected near spine margins. The first unequivocal samples of new dome lava were of vesicular "hot pink" dacite (SH304).

Progressive textural changes in fabric from undeformed fresh dacite lava to sheared, cataclastic and finely powdered fault-gouge are well documented by this sample suite. This process of active volcanic cataclasis accounts for the source material of fine airborne ash deposited within and around the volcano that was mobilized during near-vent steam explosions or large dome collapses.

All samples of both igneous and cataclastic facies of dome rock contain 1-5 volume percent of coarse-grained gabbroic to dioritic xenoliths. In nongranulated dacite talus blocks, these xenoliths 
range in size from large angular blocks $(18 \times 9 \times 6 \mathrm{~cm})$ to rounded and disaggregated mm-sized pieces. These xenoliths are similar to the xenoliths in the 1980-83 dome lava, as described by Heliker (1992). They have since been established to be of Tertiary age and are interpreted as wallrock assimilated at less than $4 \mathrm{~km}$ depth (J.S. Pallister, written communication, 2005). Sparse and generally much smaller lithic inclusions of dacite, andesite and amphibolite are also contained in both 2004-7 and 1980-86 Mount St. Helens dome lava.

Our best estimates of the eruption date of any given sample are made using the collection date and source location, coupled with the measured linear rate of spine extrusion from the vent. While a few samples of spine edges and gouge surfaces were pried or scraped in situ using Jaws, most were dredged from debris flows or talus slopes. For these samples, source locations along the growing spine are well-constrained by field documentation.

\section{Explanation of the Mount St. Helens 2004-2007 Dome Sample Catalog}

Dome Sample Catalog information is partitioned into tables 1 and 2 in OF2008-1130.xls. Table 1, Sampling Information, provides information on each of the 34 Dome sampling forays that have collectively contributed to the suite of 2004 to 2007 Mount St. Helens dome samples. Table 2, Sample Descriptions, provides information for individual rocks or lithologically grouped samples from each of the collection sites listed in table 1. The categories of sample information (column headers) for both of these tables are explained as follows.

\section{Table 1. Sampling Information}

Location Number: Sequential numbers of SH300-SH333 were assigned for each discrete sampling location, this numbering sequence continues that adopted for the Mount St. Helens reference collection from 1980-1986.

Spine Number: Sequential numbers of 1 through 7 indicate which of the seven successive lava spines was sampled.

Longitude and Latitude: The geographic coordinates of each sample recorded during sample retrieval, using either helicopter-mounted or handheld GPS instruments; values shown are referable to the World Geodetic System datum, 1984 (WGS84); latitude is positive (north) and longitude is negative (west).

Distance and Azimuth from the Vent: Distance is in meters and azimuth refers to the easterly angle from the vent to the sample. Both numbers are calculated using the sample location coordinates relative to vent coordinates of $\mathrm{N} 46.1970$ and $\mathrm{E}-122.1881$.

Date Collected: The day of sample collection

Eruption Date: Best estimates of the date of extrusion are made using collection location and date and the known linear extrusion rate from the vent location; oldest and youngest age limits specify the interval for emplacement based upon field relations.

Sampling Method: Most samples were collected by helidredge using Jaws with a chainmail basket (as described above). Two collections were done by hand, on the ground at the margins of dome talus piles and two were fortuitously collected as debris on instrument packages deployed near the vent.

Location Notes: Notations pertaining to each sample location 


\section{Table 2. Sample Descriptions}

Sample Number: All 2004 to 2007 sample numbers begin with the SH300-SH333 location number and are followed with alpha numeric designations for individual rocks or lithologically grouped fragments. Nomenclature for sub-suites that were sorted from the early lithic debris collections are further elaborated in the Sample Notes column.

Rock Facies: Each sample is categorized as one of three dome lithologies - Lava, Fault Gouge or Lithic Debris.

Field Number: Any alternate sample numbers used prior to the retroactive establishment of the SH numbering sequence are listed here in order to belay any confusion resulting from earlier sample distribution to analytical and research collaborators.

Original Sample Weight: Weight, in grams, of the bulk-sample, prior to distribution for analysis and research

Sample Notes: A short summary of field and laboratory notes about individual samples or groups of samples from the same location

\section{Analytical Methods}

Most bulk sample analyses for major- and trace-elements reported here were provided by the U.S. Geological Survey's analytical facilities in Denver, Colorado. Geochemical analyses of a subset of 2004-7 dome samples were also analyzed at Washington State University, Pullman, Washington. Both facilities were provided with similar aliquots of inclusion-free, centimeter-sized chips that were hammered from the same dome samples. Intra-laboratory results for the USGS AGV-2 standard are reported here and testify to the comparability of chemical data from different sources.

At the USGS XRF Laboratories, Tammy Hannah and Joe Taggart determined bulk rock major-element abundances using wavelength dispersive spectrometry X-ray fluorescence (WDXRF) techniques described by Taggart and Siems (2002). Standard reproducibility and precision of major-element analysis from this laboratory are given by Thornber and others (2002) [http://geopubs.wr.usgs.gov/open-file/of02-017]. This same laboratory provided bulk analysis of trace-elements by energy dispersive spectrometry X-ray fluorescence (EDXRF). Siems (2002) describes this EDXRF technique, data reduction routine and standard reproducibility for the 18 EDXRF trace-elements reported here [http://pubs.usgs.gov/of/2002/ofr-020223/U27edsfinal_U.pdf].

WDXRF analysis done at Washington State University's GeoAnalytical Laboratory in Pullman by Dianne Johnson Cornelius and Rick Conrey includes major- and trace-element abundances using methods of Johnson and others (1999) but with a newer generation spectrometer (Thermo-ARL Advant'XP+). Details on the WSU WDXRF laboratory procedures, and documentation of the precision and accuracy of their analyses are available at their website [http://www.wsu.edu/ geolab/note/xrf.html].

Analyses of 30 trace elements are reported here for bulk dome samples as determined by inductively coupled plasma mass spectrometry (ICP-MS) analysis, performed at the U.S. Geological Survey's Denver Analytical Laboratories by Monique Adams and Paul Lamothe. Methods for ICP-MS analysis are detailed in Briggs and Meier (2002) [http://pubs.usgs.gov/of/2002/ofr-02-0223/I20NAWQAPlus_M.pdf]. ICP-MS analyses of 37 trace elements, performed by Charles Knaack at WSU, are also included in this report. These data were 
obtained using a combined fusion/dissolution method, as described in Knaack and others (1994) [http://www.wsu.edu/ geolab/note/icpms.html].

We also report whole-rock abundances of 28 trace elements determined by instrumental neutron activation analysis (INAA) long-count at the USGS-Denver laboratory. A summary of the INAA procedures used is provided by Budahn and Wandless (2002), who estimate precision and accuracy for most elements as $1-5 \%$ based upon replicate analyses of USGS standard reference materials [http://pubs.usgs.gov/of/2002/ofr-02-0223/X14INAALong_M.pdf].

\section{Chemistry of Mount St. Helens 2004-2007 Dome Samples}

Bulk-rock major-element and trace-element geochemical data provided by the USGS analytical facilities are compiled for 44 Mount St. Helens 2004-7 dome samples in table 3 of the accompanying Microsoft Excel file OF08-\#\#\#.xls. This data is integrated with a subset of 19 duplicate sample analyses provided by WSU and is presented as follows.

\section{Table 3. Sample Chemistry}

The data are presented in columns for each successive sample number. Spine Number, Eruption Date are as cited in table 1 and Rock Facies are as described in table 2. The Data Source is indicated as either USGS or WSU. The data are grouped by analysis type as listed and in the following order:

1. WDXRF Major-element abundances as weight percent oxide values, normalized relative to the total of the 10 components shown (usually $>99.5$ percent with $<0.5$ percent loss on ignition) with all iron calculated as ferrous oxide (FeTO); analyses by USGS and WSU

2. ICP-MS Trace-element abundances in parts per million, analyses by USGS and WSU

3. EDXRF and WDXRF Trace-element abundances in parts per million, analyzed by EDXRF at USGS and by WDXRF at WSU

4. INAA Trace-element abundances in parts per million, determined by USGS

\section{Intra-lab AGV-2 Standard Reproducibility}

AGV-2 has been introduced as a geochemical standard to replace dwindling supplies of USGS standard AGV-1, a trachyandesite lava flow from Guano Valley, in Lake County, Oregon (Flanagan, 1976). This silicic andesite composition provides an appropriate standard of comparison for Mount St. Helens dacite. The preliminary USGS certified analysis of AGV-2 is provided on the web [http://minerals.cr.usgs.gov/geo_chem_stand/andesite2.html]. This standard is widely distributed and chemical analyses of AGV-2 from various labs by different techniques have been published in numerous journal articles. An updated list of "preferred" element concentrations for AGV-2 is maintained in the Max-Planck-Institute database for reference materials (GeoReM, Jochum and others, 2005) [http://georem.mpch-mainz.gwdg.de/]. As of February 2008, all of the GeoReM "preferred"AGV-2 concentration values for major elements and some trace elements are those of the original 1998 USGS certificate of analysis.

AGV-2 analyses from each of the analytical laboratories contributing to this report were obtained during the interval when data presented here were acquired. These intra-laboratory AGV2 analyses are compared with GeoReM "preferred" values for major elements and trace elements in tables 4 and 5, respectively. The average of 16 USGS WDXRF major-element analyses of AGV-2 from 2004 to 2007 are well within $1 \sigma$ standard deviations reported for the GeoReM "preferred" value for each element. An average of two pairs of AGV-2 analyses by WSU in 2004 and 2006 is, 
likewise, very tightly constrained to these original USGS recommended major-element values. Averaged AGV-2 trace-element analyses by USGS INAA, ICP-MS, EDXRF, and by WSU WDXRF are closely matched to GeoReM "preferred" values for a combined suite of 36 traceelements.

Table 4. Major-Element Analyses of U.S.Geological Survey Geochemical Reference Standard AGV-2

\begin{tabular}{|c|c|c|c|c|c|c|}
\hline \multirow{2}{*}{ weight $\%$ oxides } & \multicolumn{2}{|c|}{$\frac{\text { GeoRem }^{*} / \text { USGS }^{* *}}{\frac{\text { Preferred }}{\underline{\text { (02/2008) }}}}$} & \multicolumn{2}{|c|}{$\begin{array}{l}\text { USGS } \\
\frac{\text { WDXRF }}{\mathrm{N}=16}\end{array}$} & \multicolumn{2}{|c|}{$\begin{array}{c}\underline{\text { WSU }} \\
\frac{\mathrm{WDXRF}}{\mathrm{N}=4}\end{array}$} \\
\hline & Value & $1 \sigma \mathrm{SD}$ & Avg & Diff & Avg & Diff \\
\hline $\mathrm{SiO}_{2}$ & 59.3 & 0.7 & 59.1 & -0.2 & 59.4 & 0.1 \\
\hline $\mathrm{TiO}_{2}$ & 1.05 & 0.22 & 1.04 & -0.01 & 1.04 & -0.01 \\
\hline $\mathrm{Al}_{2} \mathrm{O}_{3}$ & 16.9 & 0.21 & 16.8 & -0.11 & 17.0 & 0.05 \\
\hline $\mathrm{Fe}_{2} \mathrm{O}_{3(\mathrm{t})}$ & 6.69 & 0.13 & 6.64 & -0.05 & 6.86 & 0.17 \\
\hline MnO & 0.1 & 0.004 & 0.100 & 0.000 & 0.100 & 0.000 \\
\hline MgO & 1.79 & 0.03 & 1.79 & 0.00 & 1.79 & 0.00 \\
\hline $\mathrm{CaO}$ & 5.2 & 0.13 & 5.20 & 0.00 & 5.23 & 0.03 \\
\hline $\mathrm{Na}_{2} \mathrm{O}$ & 4.19 & 0.13 & 4.07 & -0.12 & 4.24 & 0.05 \\
\hline $\mathrm{K}_{2} \mathrm{O}$ & 2.88 & 0.11 & 2.88 & 0.00 & 2.91 & 0.03 \\
\hline $\mathrm{P}_{2} \mathrm{O}_{5}$ & 0.48 & 0.02 & 0.50 & 0.02 & 0.48 & 0.00 \\
\hline Loss On Ignition & 1.3 & 0.3 & 1.4 & 0.1 & 1.3 & 0.0 \\
\hline
\end{tabular}

Table 4. Intra-lab WDXRF major-element analyses of AGV-2 obtained during the interval for which data in this report was aquired is compared to GeoReM preferred values of unnormalized weight percent oxides with total iron oxide as $\mathrm{Fe}_{2} \mathrm{O}_{3(\mathrm{t})}$. The $1 \sigma$ standard deviation is that listed for the preferred value in GeoReM, $\mathrm{N}=$ number of analyses in the average (Avg); Diff is the difference between lab values and GeoRem preferred values for each element 
Table 5. Trace -Element Analyses of U.S.Geological Survey Geochemical Reference Standard AGV-2

\begin{tabular}{|c|c|c|c|c|c|c|c|c|c|c|c|c|}
\hline \multirow[b]{3}{*}{ ppm } & \multirow{2}{*}{\multicolumn{2}{|c|}{$\frac{\text { GeoRem }^{*}}{\frac{\text { Preferred }}{(02 / 2008)}}$}} & \multicolumn{6}{|c|}{ U.S. Geological Survey } & \multicolumn{4}{|c|}{$\frac{\text { Washington State }}{\text { University }}$} \\
\hline & & & \multicolumn{2}{|c|}{$\frac{\text { INAA }}{N=2}$} & \multicolumn{2}{|c|}{$\frac{I C P-M S}{N=3}$} & \multicolumn{2}{|c|}{$\frac{\text { EDS XRF }}{\underline{N=13}}$} & \multicolumn{2}{|c|}{$\frac{\text { WDXRF }}{N=4}$} & \multicolumn{2}{|c|}{$\frac{\text { ICP-MS }}{\underline{N=2}}$} \\
\hline & Value & SD & Avg & Diff & Avg & Diff & Avg & Diff & Avg & Diff & Avg & Diff \\
\hline $\mathrm{Ba}$ & 1130 & 11 & 1160 & 30 & 1185 & 55 & 1148 & 17.9 & 1136 & 6 & 1108 & -22 \\
\hline $\mathrm{Be}$ & 2.3 & 0.4 & & & 2.4 & 0.1 & & & & & & \\
\hline $\mathrm{Ce}$ & 68.6 & 0.5 & 72.1 & 3.5 & 68.3 & -0.3 & 62.7 & -5.9 & 67.9 & -0.7 & 68.6 & 0.0 \\
\hline Co & 16 & 1 & 16 & 0 & 16 & 0 & & & & & & \\
\hline $\mathrm{Cr}$ & 16 & 1 & 16.0 & 0.0 & 17.3 & 1.3 & 20.1 & 4 & 18.0 & 2.0 & & \\
\hline Cs & 1.2 & 0.1 & 1.2 & 0.0 & 1.1 & -0.1 & & & & & & \\
\hline Dy & 3.47 & 0.03 & & & & & & & & & 3.7 & 0.3 \\
\hline $\mathrm{Er}$ & 1.81 & 0.02 & & & & & & & & & 1.1 & -0.7 \\
\hline $\mathrm{Cu}$ & 53 & 4 & & & 53 & 0 & 54 & 1 & 52 & -1 & 2 & -51 \\
\hline $\mathrm{Eu}$ & 1.53 & 0.02 & 1.54 & 0.01 & & & & & & & 1.60 & 0.07 \\
\hline $\mathbf{G a}$ & 20 & 1 & & & 20 & 0 & 20 & 0 & 20 & 0 & & \\
\hline Gd & 4.52 & 0.05 & 4.60 & 0.08 & & & & & & & 4.66 & 0.14 \\
\hline Hf & 5 & 0.1 & 5 & 0.2 & & & & & & & 5 & 0.10 \\
\hline Ho & 0.65 & 0.03 & 0.76 & 0.11 & & & & & & & 0.70 & 0.05 \\
\hline $\mathbf{K}$ & 23780 & 200 & & & 24450 & 670 & & & & & & \\
\hline La & 37.9 & 0.04 & 39.00 & 1.10 & 40.7 & 2.80 & 35.32 & -2.58 & 37.9 & 0.05 & 38.08 & 0.18 \\
\hline Li & 11 & 1 & & & 10 & -1 & & & & & & \\
\hline Lu & 0.247 & 0.004 & 0.260 & 0.013 & & & & & & & 0.247 & 0.000 \\
\hline $\mathrm{Nb}$ & 14.5 & 0.8 & & & 18.5 & 4.0 & 15.0 & 0.5 & 12.9 & -1.6 & 12.7 & -1.8 \\
\hline Nd & 30.5 & 0.1 & 32.1 & 1.6 & & & 34.3 & 3.8 & 31.4 & 0.9 & 30.3 & -0.2 \\
\hline $\mathrm{Ni}$ & 20 & 1 & 25 & 5 & 17 & -3 & 23 & 3 & 18 & -2 & & \\
\hline $\mathrm{Pb}$ & 13.2 & 0.5 & & & 13.1 & -0.1 & 13.7 & 0.5 & 13.3 & 0.1 & 13.4 & 0.2 \\
\hline $\mathrm{Pr}$ & 7.84 & 0.31 & & & & & 67.15 & 59.31 & & & 8.16 & 0.32 \\
\hline $\mathbf{R b}$ & 66.3 & 0.5 & 67.6 & 1.33 & 64.5 & 1.80 & & & 67.9 & 1.57 & 63.8 & -2.48 \\
\hline Sc & 13 & 1 & 13 & 0 & 14 & 1 & & & 13 & 0 & 12 & -1 \\
\hline Sm & 5.49 & 0.03 & 5.99 & 0.50 & & & & & & & 5.74 & 0.25 \\
\hline $\mathrm{Sr}$ & 661 & 6 & 671 & 10 & 667 & 6 & 653 & -8 & 666 & 5 & 634 & -27 \\
\hline $\mathrm{Ta}$ & 0.87 & 0.08 & 0.95 & 0.08 & & & & & & & 0.81 & -0.06 \\
\hline $\mathrm{Tb}$ & 0.64 & 0.01 & 0.64 & 0.00 & & & & & & & 0.67 & 0.03 \\
\hline Th & 6.1 & 0.2 & 6.28 & 0.18 & 6.68 & 0.58 & 4.95 & -1.15 & 5.97 & 0.13 & 6.26 & \\
\hline $\mathrm{TI}$ & 0.27 & & & & 0.29 & 0.02 & & & & & & \\
\hline $\mathrm{Tm}$ & 0.26 & 0.01 & 0.29 & 0.02 & & & & & & & 0.26 & 0.00 \\
\hline $\mathbf{U}$ & 1.86 & 0.09 & 1.95 & 0.09 & 1.95 & 0.09 & & & & & 1.87 & 0.01 \\
\hline $\mathbf{V}$ & 122 & 4 & & & 123 & 1 & 125 & 3 & 120 & -2 & & \\
\hline $\mathbf{Y}$ & 19 & 2 & & & 22 & 3 & 20 & 1 & 20 & 1 & 19 & 0 \\
\hline $\mathrm{Yb}$ & 1.62 & 0.02 & 1.71 & 0.09 & & & & & & & 1.55 & -0.07 \\
\hline $\mathrm{Zn}$ & 86 & 8 & 84 & -2 & 95 & 9 & 89 & 3 & 91 & 5 & & \\
\hline $\mathrm{Zr}$ & 230 & 4 & 222 & -8 & 237 & 7 & 237 & 7 & 226 & -4 & 211 & -19 \\
\hline
\end{tabular}


Table 5. Intra-lab trace-element analyses of AGV-2 showing GeoRem preferred values and those obtained by USGS INAA, ICP-MS, EDXRF, and by WSU WDXRF and ICP-MS during the interval for which data in this report was acquired. The $1 \sigma$ standard deviation is that listed for the preferred value in GeoReM, $\mathrm{N}=$ number of analyses in the average $(A v g)$, Diff is the difference between lab values and preferred values for each element

\section{Acknowledgments}

Nearly all of the "helidredged" samples described herein were achieved through the exceptional piloting skills of Jeff Lindscott (JL Aviation) with in-flight geological guidance from CVO staff scientists including John Pallister, Dan Dzurisin, Carl Thornber, Dave Sherrod and Steve Schilling. Matt Logan (CVO ) turned John Pallister's vision of a dredging device into reality with his creation and refinement of "Jaws". Professor John Wolff (WSU, Pullman WA), director of the NSF-supported WSU GeoAnalytical Laboratory, enabled cooperative efforts between the State of Washington and USGS to provide timely geochemical analyses of new eruption samples for monitoring and research purposes.

Authorship of this open file report recognizes (1) those who processed incoming rocks and lithic debris during this 3-year period of volcanic eruption and (2) the USGS and WSU geochemists who enthusiastically provided fast and reliable analyses of eruption products. Technical reviews by Michael Clynne and Michael Doukas helped clarify this report.

\section{References Cited}

Briggs, P.H., and Meier, A.L., 2002, The determination of forty-two elements in geological materials by inductively coupled plasma - mass spectrometry, chapter "I", in Taggart, J.E., Jr., ed., Analytical methods for chemical analysis of geologic and other materials: U.S. Geological Survey Open File Report 02-223.

Budahn, J.R. and Wandless, G.A., 2002, Instrumental neutron activation by long count, chapter "X", in Taggart, J.E. Jr., ed., Analytical methods for chemical analysis of geologic and other materials: U.S. Geological Survey Open File Report 02-223.

Flanigan, F.J., 1976, Description and analysis of Eight New USGS Rock Standards: U.S. Geological Survey Professional Paper 840, 192 p.

Heliker, C., 1995, Inclusions in Mount St. Helens dacite erupted from 1980 through 1983: Journal of Volcanology and Geothermal Research, v. 66, nos. 1-4, p. 115-135.

Jochum, K.P., Nohl, U., Herwig, K., Lammel, E., Stoll, B. and Hofmann, A.W., 2005, GeoReM: A New Geochemical Database for Reference Materials and Isotopic Standards: Geostandards and Geoanalytical Research, v. 29, no. 3, p.333-338

Johnson, D.M., Hooper P.R., and Conrey, R.M., 1999, XRF Analysis of Rocks and Minerals for Major and Trace-elements on a Single Low Dilution Li-tetraborate Fused Bead Advances in Xray Analysis, v. 41, p. 843-867.

Knaack, C., Cornelius, S., and Hooper, P.R., 1994, Trace element Analysis of Rocks and Minerals by ICP-MS:Technical Notes, Department of Geology, Washington State University, http://www.wsu.edu/ geolab/note/icpms.html

Rowe, M.C., Thornber, C.R., Gooding, D.J., and Pallister, J.S., 2008, Catalog of Mount St. Helens 2004-2005 Tephra Samples with Major and Trace-element Geochemistry: U.S. Geological Survey Open File Report 2008-1131, 7p. with digital database.

Sherrod, D.R., Scott, W.E., and Stauffer, P.H., 2008, eds., A volcano rekindled: the renewed eruption of Mount St. Helens, 2004-2006: U.S. Geological Survey Professional Paper 1750. 
Siems, D.F., 2002, The Determination of 30 Elements in Geological Materials by EnergyDispersive X-ray Fluorescence Spectrometry, chapter "U”, in Taggart, J.E. Jr., ed., Analytical methods for chemical analysis of geologic and other materials: U.S. Geological Survey Open File Report 02-223.

Taggart, J.E. and Siems, D.F., 2002, Major-element analysis by wavelength dispersive x ray fluorescence spectrometry, chapter "T", in Taggart, J.E. Jr., ed., Analytical methods for chemical analysis of geologic and other materials: U.S. Geological Survey Open File Report 02-223.

Thornber, C.R., Budahn, J.R., Ridley, W.I. and Unruh, D.M., 2003, Trace-element and Nd, Sr, Pb isotope geochemistry of Kilauea Volcano, Hawaii, near-vent eruptive products: 1983-2001, U.S. Geological Survey Open File Report 03-493 ,5 p. with digital database.

Thornber, C.R., Sherrod, D.R., Siems, D.F., Heliker, C.C., Meeker, G.P., Oscarson, R.L. and Kauahikaua, J.P., 2002, Whole-rock and glass major-element geochemistry of Kilauea Volcano, Hawaii, near-vent eruptive products: September 1994 through September 2001, U.S. Geological Survey Open File Report 02-17, 9 p. with digital database. 